satisfactory, as a prominence $60^{\prime \prime}$ in height will remain visible and simply appear to oscillate during a whole rotation. It is suggested, however, that satisfactory determinations of the polar rotation in high latitudes could be made by observing these prominences, whereas the sunspot observation method cannot be applied and the spectroscopic method is unsatisfactory.

Observations of Variable Stars.-The periods and light-changes of several variable stars are discussed in Bulletins Nos. $I_{5}$ and 16 of the Laws Observatory, University of Missouri. No. I5 is devoted to the discussion of 395 observations of the Algol variable RW Monocerotis (24, 1907) made during the period October, 1907, to April, 1908 , and a period of $x \cdot 9 \mathrm{~d}$. is deduced, the light-changes taking place in $7 \mathrm{~h} .34 \mathrm{~m}$.

The observations of the long-period Algol variable RZ Ophiuchi are discussed in Bulletin No. 16 , and a period of $26 \mathrm{I} .8 \mathrm{~d}$. is found to satisfy them. The other variables, for which only preliminary announcements are given, are RS Boötis, 43.1907 Draconis, 44.1907 Ursæ Majoris, and SW Andromedæ $(5,1907)$.

The Influence of the Earth's Rotation on the Courses of Rivers.--In a paper published in the Transactions of the New Zealand Institute (vol. xxxix., pp. 2072r3) Dr. F. W. Hilgendorf discusses some very careful observations made by himself of the possible influence of the earth's rotation on the course of the rivers which flow over the Canterbury Plains, New Zealand. These plains, being of a very homogeneous structure, afford an excellent site for the testing of "Ferrel's law" concerning the deflecting force of the earth's rotation, and Dr. Hilgendorf succeeds in showing that this deflecting force has, in all probability, been an effective factor in the modification of the banks of the rivers which flow in a N.E.-S.W. direction across the Canterbury plains.

A Possibly Undiscovered Form of Solar Radiation. -In No. 5 of the Comptes rendus (p. 318 , vol. cxlvii., August 3) M. E. Durand-Gréville discussed the secondary twilight and dawn which arc observed in the Alps and at other great altitudes, and suggested that reflection of the sunlight from the temperature-reversing layer of the atmosphere, discovered by $M$. Teisserenc de Bort, might account for these phenomena; but in No. 7 of the Comptes rendus (August 17 ) M. Deslandres offers an alternative suggestion. It is that, in addition to the solar radiations which traverse our atmosphere and those ultra-violet radiations which are known to be absorbed by it, there may be others, in the further ultra-violet, to which the atmosphere may be transparent or which are able to produce a phosphorescence which would account for the secondary illumination of the mountain sides, \&c., after the passing of the ordinary twilight. He further suggests a method whereby the ( xistence of such radiations may be demonstrated.

\section{WELSH ASTRONOMICAL TRADITIONS}

I HAVE put together some notes, compiled out of the flotsam and jetsam of Welsh tradition bearing on the continuity of the astronomy of the stone monuments, with the view of finding out how far such traditional matcrials will enable us to reconstruct, with the aid of the testimony of the monuments themselves, the story of the megalithic period in Britain, the period or periods of the avenue, circle, and cromlech.

\section{The Testimony of the Bards.}

I have already in these columns claimed for the Gorsedd a continuity of bardic tradition of the greatest value. A more careful study of isolated bardic utterances shows us the bard-astronomer at work in the same capacity as the priest-astronomer of the megalithic period.

There are two utterances attributed to the bard Taliesin which strongly suggest the use of stars as heralds of sunrise or as clock stars. In such utterances the note of antiquity is the bard's assumption of exclusive know. ledge of astronomical phenomena. He challenges others to tell him "what hour in the small of the day (meinddydd) that Cwy was born?" Who Cwy was I know not, but the expression should be remembered in discussing Welsh solar heroes. Again, the bard speaks contemptuously of NO. 2027 , VOL. 78 ] some who " do not know the point of separation between dewaint (the midnight watch, I to 3 ) and gwawr (dawn).'

It should be remembered that the body of tradition we are discussing was once common to the inhabitants of Wales as Goidelic or Irish before it became Welsh. The Irish bard Amairgen speaks still more definitely of his indispensableness :- -

"Who foretells the ages of the moon (but I)?

Who teaches the spot where the sun rests (but I)?"

The sun rests at the solstice. People from the earliest times would have noted as much. But the spot-who but the bard knew the solstitial alignment? The words take us back not only to a period before the popular use of a calendar, but also to the time when the almanac for the year was fixed by direct observation of the solstice sun on the horizon; not that observation of the solstice along the horizon is in itself a proof of antiquity, for a farmer in the parish from which I write still uses that ancient method; but what is curious is the bard's assumption of exclusive credit for the information.

The leading astronomers of bardic tradition are mythical personages. I have elsewhere shown how the leading saints of Wales were regarded as astronomers. But the leading astronomers were the associates of gods, if not gods themselves. "The three sublime astronomers of the Isle of Britain :--Idris the Giant, Gwydion the son of Don, and Gwyn the son of Nudd. So great was their knowledge of the stars, and of their nature and situation, that they could foretell whatever might be desired to be known to the day of doom."

Idris is commemorated in the name of the Merionethshire mountain, Cadair Idris (Idris's Chair). The Milky Way is called Caer. Gwydion (Gwydion's Encampment). His mother was a goddess. Gwyn, the son of Nudd, is spoken of as the King of the Fairies. His father seems to have been the Welsh Neptune.

So the remotest antiquity and the place of highest importance is given to astronomy in Welsh or British tradition.

\section{Holed Stones.}

These are rather rare monuments. I have notes of some in Wales, and I expect, with the growth of interest in the astronomical study of such monuments, that more will be brought to light. As Cornish and Scottish tradition shows, such stones were used as charms, a fact which largely explains their present rarity.

I have not been able to find out the origin of a familiar Cardiganshire expression. When one makes a vain attempt to make another person understand or heed what is told him, the speaker or a friend makes the remark. "You might as well say Carreg a Thwll (Stone and Hole) to him." This cryptical Welsh expression is the name of the famous holed stone of Cornwall, Men-anTol, so that the Welsh colloquial Carreg a Thwll may reasonably be supposed to be the holed stone of the megalithic period.

A holed stone figures prominently in one of our oldest written tales, namely, the tale of 'Math, son of Mathonwy. The stone was on the bank of the river Cynvael in Ardudwy, a part of Merionethshire, and it was called Llech Gronw, "the Stone of Gronw or Goronwy." Gronw loved, and was loved by, the wife of Llew Llew Gyffes, "Llew of the Un-erring Hand." The woman induced her husband to tell her how he might be slain, pretending the most affectionate concern in such an event. He told her gladly, "Not easily can I be slain, except by a wound. And the spear wherewith I am struck must be a year in the forming. And nothing must be done towards it except during the sacrifice on Sundays. I cannot be slain within a house, nor without. I cannot be slain on horseback nor on foot." "Verily," said she " in what manner then canst thou be slain?" "I will tell thee," said he. "By making a bath for me by the side of the river, and by putting a roof over the cauldron, and thatching it well and tightly, and bringing a buck, and putting it besides the cauldron. Then if I place one foot on the buck's back, and the other on the edge of the cauldron, whosoever strikes me thus will cause my death."

The woman's paramour toiled for a whole year making 
the spear, and one day Llew was induced by his wife to stand in the position by the cauldron he had indicated. "Thereupon Gronw rose up from the hill which is called Bryn Cyfergyr, and he rested on one knee, and flung the poisoned dart and struck him (Llew) on the side, so that the shaft started out, but the head of the dart remained in." Llew was, as we would say, mortally wounded, but nobody dies in the Mabinogion tales. They simply become transformed. Llew reappeared to return exactly the same compliment to Gronw. The latter begged of Llew to allow a stone to be placed between him and the marksman. "Then Llew flung the dart at him, and it pierced the slab and went through Gronw likewise, so that it pierced through his back."

At first sight the whole story might be regarded as a clumsy attempt at explaining the holed stone and its name. But what of the very curious details of this fabulous Order of the Bath?

The following considerations offer themselves. The typical wizard in Welsh tradition orders his body to be buried neither within nor without the church. "Stand. ing with one foot in the grave" is a familiar expression. The picture of a man standing with one foot on the cauldron and the other on a buck's back brings to my mind another legendary picture of a man visiting a cave, where hidden treasures lie, on a cow's back. It was necessary for him to enter into the cave and return without dismounting, and he was allowed to pick up as much of the treasure as he could grab at on that bovine ride. The two Welsh words "bwch," "buck," and "buwch," "cow," are similar enough to become confused in such tales.

I would assume that the holed stone Llech Gronw was a solstitial sight-line from a circle or cromlech to the point on the horizon where the marksman stood to throw the dart. Such a sight-line was of no use except once a year, as the sun would only call once a year at that point. The spear was a year in the making. Sundays may be regarded as the moon's quarters, and though a solstitial cromlech or alignment was of use only once a year, there is evidence of a weekly ceremony of some sort at such monuments. The "curate" in charge of an astronomical monument had, like other curates, his work to do all the year round.

A holed stone between a specified hill-point and a covered structure-we have here the complete apparatus for observation from an allée couverte. To the archæologist, however, the holed stone is now a telescope reversed-that is, it is of use not to observe sunrise so much as to find hidden parts of the original alignment. Sir Norman Lockyer, in "Stonehenge," has shown that "holed stones were arrangements for determining alignments," and he tells us how an ancient stone alignment was traced from a circle to holed stones at Tregaseal (p. 282).

The utility of the holed stone as a path-finder, so to speak, has been proved by Dr. Baudouin, in France. At the third "Prchistoric" congress of France last year (reported in Nature, October 24, 1907, p. 649), he showed that "menhirs were indicators of megalithic sepultures." "By using two certain holed stones as indicators, he was enabled to discover an allée couverte which was buried under the soil, and had until then remained undiscovered. This 'find,' made with remarkable scientific precision, was received by numerous foreign congressists as a striking example of the value of a theory which many of them still ignore."

The best oral tradition of a cave with sleeping warriors guarding treasure I have been able to collect at first hand is widely known at Devil's Bridge, Cardiganshire. All the story, which I have dove-tailed out of five versions, would occupy more space than I can reasonably expect to have here. Though it is known that the cave is situate on a woody slope on the farm of Tynycastell on the south side of the river Rheidol, no one living has seen it. But tradition has it that the mouth of the cave is sometimes seen from some point on Penrhiw farm on the north or opposite side of the valley. If my recollection is correct, that farm is north-east, and on the sky-line, from the traditional site of the cave, and if a careful search were made for some alignment or indicator at
Penrhiw, possibly the hidden cave might be re-discovered. At any rate, the fact that the mouth of the cave used to be seen from Penrhiw indicates that the cave was a summer solstice allée couverte. This is further confirmed by the tradition that the mouth of the cave was to be seen from Penrhiw only once a year. These inferences as to the solstitial use of the cave are amply confirmed by the most definite local tradition.

This was the cave where the visitor had to enter and leave on a cow's back. Another version has it that there were three steps into the cave. When the visitor stood on the first step, a sleeping warrior inside awoke; when he stood on the second step, the warrior laid his hand on his sword; and when he stood on the third, the warrior cut off witl his sword the lighted head of the candle which the visitor held in his hand. Another version simply gives it that when the visitor entered a warrior awoke and asked, "A ddaeth y tri bore'n un?" (Have the three mornings become one?) For about five years I kept troubling our folklore authorities for an explanation of that strange question, and quite in vain. Sir Norman Lockyer solved the conundrum by return of post. The three mornings in one are the three days of the solstice, when the sun stands still, and because of that apparent stationariness the three days were reckoned as one.

I believe that the well-known tradition at Devil's Bridge of a demon or hero imprisoned in a rock is a part, if not the leading part, of the cave legend of Tynycastell close by. He is popularly believed to be working his way out of a rock a "fathom" deep with " an ounce hammer and a clog nail," or, as a more degenerate tradition has it, " an ounce hanmer and a carpet-tack."

So much about a living tradition of a solstitial cromlech in actual use, and a tradition which has apparently survived the cromlech itself. By the bye, the "cave" is never a tomb. Its occupants are always alive, alive not as mere ghosts. Mr. T. H. Thomas has observed that "wraiths of human guardians, or inhabitants, are rare about cromlechs, while they are remarkably numerous about tumuli." While the cromlech in most instances seems to have been converted into a tomb, it is interesting to note that its folklore associations must have become fixed before such a conversion, and agree with and elucidate the astronomical interpretation of the use of the cromlech.

JoHn GRIFFITH.

\section{THE PRAGUE EXHIBITION.}

FOR commercial purposes, the kingdom of Bohemia is divided into five districts, each under an officially recognised chamber of commerce. The district of the Prague Chamber of Commerce is the largest and most important of these. It has a population of two millions, a third of the population of the kingdom, and includes many of the chief centres of industry. The organisation of the Jubilee Exhibition at Prague is due to the enterprise of the committee of the Prague Chamber of Conmerce. From every point of view the exhibition is a success. It is attracting a daily attendance of from 10,000 to 60,000 persons, who come from all parts of the world. The exhibition occupies an enclosure in a beautiful, wellwooded park on the outskirts of the city. In the effective design and picturesque arrangement of its buildings it is a model of what such an exhibition should be.

As would be expected, the character of the exhibition is definitely commercial; but pure art is not entirely neglected, and the orchestral concerts of the Bohemian Philharmonic Association are of a high order. No fewer than eighteen imposing pavilions have been specially built, and in addition use is made of a permanent building, erected originally for the exhibition of 1891 . These buildings are devoted to the City of Prague, the chamber of commerce, machinery, the cities of the district, ceramic and glass industries, schools, goldsmiths' work, food, metal work, leather industries, chemical industries, graphic arts, photography, commerce, and temporary exhibits. Speaking generally, the exhibits in all departments show a high standard of design, finish, and workmanship. In view of the fact that many of the industries mentioned have only been established in Bohemia in recent years, the high quality of the manufactures is certainly remarkable. 